Federal Reserve Bank of Minneapolis Quarterly Review

Winter 1984

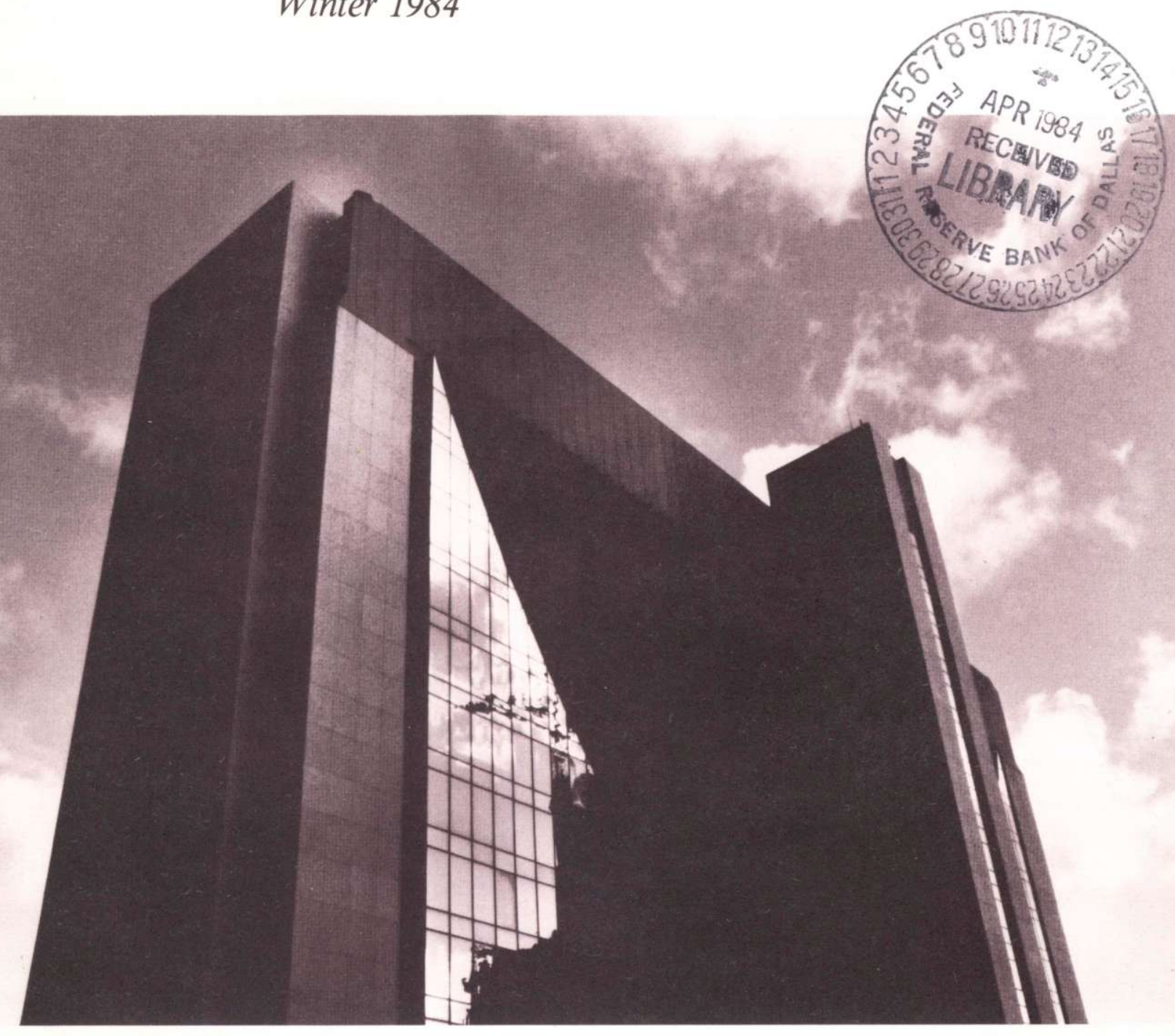

Money and Inflation in Colonial Massachusetts

Bruce D. Smith (p. 1)

Some of the Choices for Monetary Policy

Neil Wallace (p. 15) 
Federal Reserve Bank of Minneapolis

\section{Quarterly Review vol. 8, No.1 ISSN 0271-5287}

This publication primarily presents economic research aimed at improving policymaking by the Federal Reserve System and other governmental authorities.

Produced in the Research Department. Edited by Preston J. Miller, Richard M. Todd, and Inga Velde.

Graphic design by Phil Swenson and typesetting by Barbara Cahlander and Terri Desormey, Graphic Services Department.

Address requests for additional copies to the Research Department,

Federal Reserve Bank, Minneapolis, Minnesota 55480.

Articles may be reprinted if the source is credited and the Research

Department is provided with copies of reprints.

The views expressed herein are those of the authors and not necessarily those of the Federal Reserve Bank of Minneapolis or the Federal Reserve System. 


\title{
Money and Inflation in Colonial Massachusetts*
}

\author{
Bruce D. Smith
}

\section{Economist}

Research Department

Federal Reserve Bank of Minneapolis

A view common to nearly all economists is that, over a sufficiently long period of time, the rate of growth of the money supply is the key determinant of the rate of inflation. An extreme (but not uncommon) version of this view is that inflation can be controlled merely by preventing rapid growth of money, independently of other forces at work in an economy. The idea that rates of money growth and inflation are intimately related is based, at least in part, on what might be called a naive version of the quantity theory of money. This theory suggests that, in some long-run average sense, the rate of inflation will roughly equal the rate of money growth less the growth rate of real output. The purpose of this paper is to call into question the existence of any direct link between the rate of growth of the money supply and inflation. More specifically, the paper suggests that the growth of the money supply, taken by itself, is of little significance in determining the rate of inflation an economy experiences.

The point of departure for this argument is a relatively recent body of theoretical developments in monetary economics associated with the work of Thomas Sargent (1981) and Neil Wallace (1981). These developments suggest that the effects of changes in the money supply cannot correctly be analyzed without simultaneously considering prevailing fiscal policy. In order to make the argument simple, it is helpful to begin by considering monetary systems which are not fiat in nature, or in which money is backed. All this means is that when money is injected into an economy, it is either a direct claim on some commodity (such as gold or silver) or the government is committed to retire money at some future dates. In the latter case, where the government is com- mitted to retire money, this must be done by running future budget surpluses. Under such circumstances, money is said to be backed by future tax receipts.

In either case, it is easy to see that the value placed on money in the marketplace must be closely related to the government's current and future balance sheets. In the first case, where money is backed by commodities, the ability of the government to honor claims against it depends directly on its current position and its anticipated future income stream. Then, since the value of any claim is determined in part by the issuer's ability to honor it, the value of money will depend in a direct way on the government's outstanding debt, current assets, and on expected surpluses or deficits. In the second case, where money is backed by a commitment to run future surpluses, the reasoning is similar. Here money is injected into the economy with the commitment that it will eventually be withdrawn. If this commitment is not honored, the economy will be left with a permanently higher stock of unbacked money. Few would dispute that this is a stimulus to inflation.

Thus, when money is backed, its value depends on the government's balance sheet-that is, on the course of government surpluses and deficits. But all that backing necessarily means here is that increases in the money supply are accompanied by a government commitment to increase future income streams. Even if there is no ex-

*I am much indebted to John McCusker for his kind efforts to educate me about colonial monetary arrangements; to Russ Menard, without whose help I could never have undertaken this project; and to Bennett McCallum, who pointed out some errors which appeared in earlier drafts. None of these individuals bears any responsibility for the views expressed here or for any errors that might remain. 
plicit commitment to back currency, then, in a regime with fiat money (where no explicit promise of backing is made), appropriate fiscal policy can implicitly back money. In short, the view espoused here is that it is inadequate to look only at rates of growth of the money supply in considering the inflationary impact of monetary changes; the time path of fiscal policy must also be taken into consideration.

This view, which for the purposes of this paper will be called the Sargent-Wallace view, can also be thought of as follows: the value of government liabilities (including money) is determined in exactly the same way as the value of liabilities issued by private agents (such as firms). In order to see the force of this comparison, it is useful to consider what might be expected to happen to the price of a given firm's shares if the number of its shares outstanding doubles. One possibility is a stock split in which this increase in shares outstanding is not accompanied by any prospective improvement in the firm's future stream of net revenues. In this case, since there are twice as many claims on the same quantity of resources, one expects a halving in the price of the firm's shares. Similarly, in the case where a government issues additional liabilities (prints money) without an increase in its prospective net tax receipts, one expects the value of its liabilities to fall (inflation). Notice, then, that when a government increases the stock of unbacked liabilities, the Sargent-Wallace view delivers the implication that inflation should occur.

A second possibility exists when a firm issues additional shares, however. This is that the increase in outstanding shares may be accompanied by an increase in the future income prospects of the firm. In this case the price of the firm's stock may or may not fall, depending on the relative magnitudes of the two increases. Similarly, when a government issues new liabilities, inflation need not occur so long as that government simultaneously takes steps to improve its net flow of tax receipts. Hence, prevailing fiscal policy must be taken into account in attempting to evaluate the inflationary impact of any possible changes in the money supply.

The comparison between claims against a government and claims against a private agent is now clear: the value of any such liabilities depends on the ability to honor them, that is, on future income streams. Thus Sargent $(1981$, p. 5), in describing several past inflationary episodes, has likened a government to "a firm whose prospective receipts were its future tax collections. The value of the government's debt was, to a first approximation, equal to the present value of current and future government surpluses." Notice that, according to the SargentWallace view, it is possible for money to be more or less carefully backed, depending on the government's ability to honor claims against it.

This paper presents evidence that the value of money depends, in large part, on how carefully it is backed. In turn, the paper also suggests that underlying fiscal policies are far more important in determining the rate of inflation than are rates of money growth. All this is done by considering the way in which the colony of Massachusetts ended a severe long-term inflation in 1750 .

\section{Why Colonial Massachusetts?}

In order to see the reason for the focus on colonial Massachusetts, consider the following set of circumstances, reminiscent of much U.S. experience in the 1970s. A sustained inflation is in progress. The governments of important trading partners resist suggestions that they should run tight monetary policies. A large, sustained balance-of-payments deficit exists, and exchange rates have depreciated substantially. Most economists would argue that these problems could not be cured quickly, except at great social cost. But in 1750, Massachusetts faced this set of circumstances and, in a few months, arrested both inflation and the depreciation of its currency with minimal economic disruption.

Moreover, the nature of the inflation problem in Massachusetts was far more severe than that faced by the United States in the 1970s. For instance, from 1950 to 1980, prices in the United States rose 301 percent, while from 1720 to 1750 , prices in Massachusetts increased 618 percent. During the decade 1970-80, the annual inflation rate in the United States never rose above 13.3 percent; in contrast, from 1745 until 1749 the annual inflation rate in Massachusetts never fell below 19 percent. Yet in 1750 Massachusetts abruptly ended its inflation and currency depreciation. Thereafter, price stability was maintained for the next 25 years (with some exception during the French and Indian War) even though rates of money growth were high. Thus, as will be seen, large growth in the money supply is consistent with stable prices, provided that appropriate fiscal policies are carried out in the background.

A natural question concerns the significance of this particular historical episode. By itself, it is at best a curious episode in monetary history. However, Smith 
$(1983 \mathrm{a}, \mathrm{b})$ documents that all colonial American experiences are similar in that they suggest factors other than money growth rates were responsible for changes over time in price levels. Also, Sargent (1981) provides evidence that four European hyperinflations in the 1920s were ended by expedients similar to those employed in colonial Massachusetts. The similarity of experiences across American colonies in the eighteenth century and between those colonies, on the one hand, and certain European countries in the twentieth century, on the other, suggests that a general principle is at work in all of these cases. This is that inflation is caused, not by growth in the money supply directly, but by a failure to adequately back additional currency by adopting appropriate fiscal policies.

\section{Other Reasons to Study Massachusetts}

As already indicated, Massachusetts dealt successfully with a problem of long-term inflation and currency depreciation. The methods used to attack these problems were also used, with some variation, in other countries and time periods to successfully end extremely severe inflationary episodes. This alone would render the monetary system of colonial Massachusetts worthy of study. However, beyond this, there are several aspects of this system which make it an attractive one to study.

First, with two relatively short-lived exceptions around 1740, this system had no privately operated banks. This implies that several complications arising in the study of modern economies can be avoided. In particular, it is not necessary to make arbitrary decisions about which aggregate of government liabilities and private intermediary deposits is to be considered as money. Also, because the money supply of the colony did not consist in part of privately issued liabilities, it is not necessary to disentangle the effects on the money supply of changes in base money from changes in bank regulations. In short, the simplicity of the colonial economy makes it easier to interpret monetary changes and their effects.

Second, as will be seen, Massachusetts ended its inflation via a currency reform which essentially changed the way in which its currency was backed. An advantage of Massachusetts' pre- and post-reform currency systems is that the precise sense in which money was backed before and after the reform is quite easy to ascertain and describe. Such a task would be far more formidable for most modern monetary systems and for most historical changes in monetary regimes.

\section{Money in Massachusetts: 1720-50}

The money supply of colonial Massachusetts from 1720 until 1750 consisted of coins and paper currency. The coins in circulation were minted abroad and originated in several countries. This study will deal primarily with paper currency rather than circulating coins (or specie) for three reasons. First, data on specie circulation are simply unavailable, so that any quantitative discussion is not possible. Second, it will be recalled that the SargentWallace view of money is that money should be regarded as a claim against its issuer. Thus, according to this view, the paper currency issued by Massachusetts might be valued quite differently from currency issued by other governments, and so should be considered separately. Third, this approach is also consistent with a version of the other view of money mentioned above-the quantity theory of money. Massachusetts and the other colonies ran essentially independent monetary policies. A simple version of the quantity theory, then, would be to view Massachusetts as a country with its own currency and, even though other currencies might circulate within its borders, to attempt to relate price levels to the money supply of the colony itself. ${ }^{\prime}$

Is it possible, then, that the omission of specie seriously biases the findings of this paper? The answer is no, for two reasons. First, as will be seen, the quantity theory performs quite well when applied to New England before 1750. This suggests the appropriateness of matching price level movements with the stock of paper currency. Second and more important, however, is the nature of the evidence presented here. In particular, it will be shown that after 1750, extremely high rates of change in the stock of paper currency in Massachusetts did not induce any large price level movements. A defender of the proposition that inflation is determined by growth in the money supply might then respond by questioning whether movements in the stock of paper currency correctly reflect movements in the overall money supply. Or, more specifically, it might be suggested that changes in the quantity of circulating specie may have largely counteracted changes in the quantity of paper money in circulation. This defense is untenable, however. After 1750 no evidence exists of any negative correlation between the quantity of specie and the quantity of notes in

'This version of the quantity theory has been applied to Latin America by Vogel (1974). Later in this article, New England is also considered as a unified entity to which the quantity theory is applied. 
circulation. Moreover, according to Alexander Hamilton, on the eve of the Revolution money was divided into roughly three-quarters paper currency and onequarter specie. Hence in some of the episodes to be examined-for example, where the paper currency stock increases by a factor of six and prices fall-it is simply not possible for specie flows to have offset much of the change in the paper currency stock. Finally, there is every reason to think that (after 1750) movements in the stock of paper currency and movements in the stock of circulating specie were positively rather than negatively correlated. The basis for this suggestion is quite simple. After 1754 , the paper currency stock increased rapidly into the early 1760 s and then declined rapidly. This was because large deficits were being monetized during the French and Indian War. After the war, taxes levied to retire notes took effect and resulted in a monetary contraction. Similarly, during the war, British shipment of specie to the colonies was relatively high. After the war, the wellknown British taxes imposed on the colonies siphoned off specie. Hence for the period of time when the quantity theory of money clearly fails, movements in the stock of specie should largely parallel changes in the stock of paper money outstanding, so that focusing only on paper currency should not give an overly biased picture of overall monetary changes. Thus, no further apology for the absence of data on specie circulation will be offered in the discussion that follows.

In addition to specie, paper money, consisting of two types of notes, circulated in colonial Massachusetts between 1720 and 1750 . Both types were called bills of credit and were liabilities of the colonial government. One type was issued directly by the government of the colony to cover shortfalls of revenue; the other was issued by an entity known as a colonial loan office, or land bank. Both types of notes were issued in quantities and amounts determined by the colonial legislature, subject to the approval of the governor of the colony. Since the quantity of specie in circulation at any given time depended primarily on the trade balance of the colony, the quantity of notes in circulation was the only component of the money supply at the discretion of the colonial government. In addition, since New England was fairly integrated in economic terms, notes issued by Rhode Island, New Hampshire, and Connecticut enjoyed wide circulation in Massachusetts. ${ }^{2}$

While notes issued to finance expenditures are a familiar item, the institution of a land bank is not. There- fore, it seems appropriate to devote some time to a brief description of its functions, which were as follows. The colonial legislature would approve a land bank issue of $£ x$ of notes, denominated in Massachusetts currency. These notes were to be loaned out by the loan office to private individuals whose loans were secured by mortgages on land, or on gold or silver plate. In principle, these loans were to be made in amounts not to exceed one-half the value of the asset mortgaged, and there were upper and lower limits on the amount that could be lent. The individuals who received these loans were selected by town councils, which were mobilized to make loans, evaluate loan security, and the like. Loans were typically made at 6 percent interest per annum, which seems to have been at or below prevailing (private) market rates.

Whenever any notes were issued, provisions were made simultaneously for their retirement. These provisions were as follows. In the case of bills of credit issued directly by the treasury, any issue of such bills was accompanied by a set of future tax levies. These additional taxes could be paid using notes which, as they were received for these taxes, were to be retired. Hence this created an obvious mechanism by which current increases in the money supply were to be counteracted by future monetary reductions. In the case of bills of credit issued through a land bank, the loan office would accept its own notes at par (face value) for repayment of principal on loans. As notes came in from repayment of principal, they were destroyed. (Profits earned from the payment of interest on loans were used to fund general expenditures.) If principal was repaid in specie, this was used to purchase and destroy notes. In the event of default on a loan, the mortgaged property was to be auctioned off by the colony, with the proceeds used to obtain and retire notes. Thus, saying that these loan-office notes were backed means that they were backed by the promised future receipts of the loan office, either in the form of repayment of principal or of the proceeds from auctions.

In what sense were the various colonial notes money, as the term is typically used? The notes issued prior to 1750 were legal tender and negotiable. The government of the colony was obligated to accept them in payment of all debts to the state. In addition, prior to 1750 these

${ }^{2}$ Privately issued bills of exchange (private IOUs) also circulated widely. These were not payable on demand, so they were not like modern intermediary liabilities. Instead, they seem much more like modern assets for which secondary markets exist-assets not typically viewed as part of the money supply. 
notes were irredeemable; that is, they were not convertible into a commodity or any other asset on demand. Thus, these notes had most of the essential features of modern paper money.

In light of modern arrangements, the one apparently anomalous feature of Massachusetts' monetary systemas well as the systems of the other colonies-was its being so closely tied to mortgages on land. In fact, the initial loan offices were established by the colonies to deal with two unrelated problems. The first had to do with the fact that specie in circulation tended to be in large denominations relative to the average income or wealth of the population. This created a problem in revenue collection for colonial governments because many people found it difficult to obtain specie simply to pay taxes. Various solutions to this problem were adopted prior to the creation of loan offices, such as designating some commodity as legal tender for payment of taxes. These measures proved inadequate and were eliminated as one of the functions the loan offices assumed was issuing small-denomination notes to overcome the revenue collection problem (Hanson 1979, 1980 and Lester 1938, 1939).

The second problem faced by colonial governments related to how vast amounts of land were to be distributed in a reasonably equitable manner. In particular, many colonies wished to prevent the creation of a landed aristocracy. Consequently, the land banks were intended as a means by which land ownership was made feasible for a larger segment of the population. Whether or not land banks were successful in this aim seems an open question, but for the purposes of this analysis it need only be noted that the loan office system was meant to address these two problems. This accounts for many of its apparently incongruous features.

\section{Inflation in Massachusetts: 1720-49}

From 1720 to 1749 , Massachusetts experienced severe inflation and a steady currency depreciation. To give a feel for their magnitude and causes, this section presents data on inflation and currency depreciation in the colony. Data on the rate of growth in the supply of paper money are also presented.

Table 1 presents rates of inflation in the prices of two key commodities for the city of Boston. ${ }^{3}$ First, rates of inflation are presented for five-year intervals. For much of the period, this gives a fairly adequate picture of the long-term inflationary experience of the colony. As can be seen, inflation was steady, although from the data available it is not always easy to get a clear picture of its magnitude. As an example, from 1735 until 1740 the price of wheat fell (the only fall in the sample), while the price of molasses rose 69 percent (the largest five-year change in its price in the sample). However, it is clear from Table 1 that there was considerable inflation over the period.

Table 2 presents price levels for the same period. As can be seen, from 1725 to 1735 the price of molasses more than doubled, and from 1735 to 1745 it doubled again. From 1745 to 1749 it increased 59 percent. Thus, with prices of one of the commodities at least doubling every decade, it is clear that inflation was a significant and long-standing phenomenon.

In addition, yearly inflation rates for the commodity prices after 1744 are presented in the lower part of Table 1. From 1744 until 1748, inflation in the price of molasses averaged more than 25 percent per year. Inflation in the price of wheat escalated from 19.5 percent per year over $1744-45$ to about 66 percent per year in 1747-48. Since U.S. inflation over the 1970 s never exceeded 13.3 percent per year, clearly 1744-48 in Massachusetts was a dramatic inflationary episode.

The experience of Massachusetts with currency depreciation adds further evidence on the eroding value of its notes between 1720 and 1749. Data on the depreciation of Massachusetts currency are presented in Table 3. The picture is qualitatively similar to that for commodity prices. From 1720 onward there was a fairly steady depreciation of Massachusetts currency against the British pound sterling. As a result, in 1749 one pound in Massachusetts currency would purchase little more than onefifth the number of British pounds it had purchased in 1720 -a 371 percent depreciation over the thirty years. During the last four years of the period, 1745-49, Massachusetts currency depreciated 60 percent against sterling. This coincides with a period of severe inflation, confirming the extent to which the value of paper currency was eroding.

\footnotetext{
${ }^{3}$ This is effectively all the available data for commodity prices in Massachusetts. No aggregate price indices appear to have been constructed; therefore, in what follows, prices for both commodities are presented. The figures presented are wholesale prices. In addition, because these are agricultural commodity prices, rates of price increase for these commodities in silver-equivalence units are also presented to indicate that monetary rather than natural forces were responsible for most of the inflation. In fact, for the purposes at hand, there appears to be general agreement among historians that these commodity prices adequately reflect inflationary forces.
} 
Tables 1 and 2

\section{Severe inflation occurred in Massachusetts between 1720 and 1749 .}

Table 1 Inflation Rates in Massachusetts: 1720-49 (percentage rate of change in wholesale prices)

\begin{tabular}{|c|c|c|c|c|}
\hline \multirow[b]{2}{*}{$\begin{array}{c}\text { 5-Year } \\
\text { Intervals. }\end{array}$} & \multicolumn{2}{|c|}{ Wheat } & \multicolumn{2}{|c|}{ Molasses } \\
\hline & $\begin{array}{c}\text { Mass. } \\
\text { Shillings }\end{array}$ & $\begin{array}{l}\text { Silver- } \\
\text { Equivalence } \\
\text { Units** }\end{array}$ & $\begin{array}{l}\text { Mass. } \\
\text { Shillings }\end{array}$ & $\begin{array}{c}\text { Silver- } \\
\text { Equivalence } \\
\text { Units** }\end{array}$ \\
\hline $1720-25$ & $24.7 \%$ & $-1.2 \%$ & $0.0 \%$ & $-21.1 \%$ \\
\hline $1725-30$ & 33.1 & -4.3 & 50.0 & 16.7 \\
\hline $1730-35$ & 23.2 & -10.1 & 57.7 & 15.2 \\
\hline $1735-40$ & -1.9 & - & 69.1 & - \\
\hline $1740-45$ & 37.8 & - & 19.3 & - \\
\hline $1745-49$ & 180.4 & 67.6 & 59.0 & 5.9 \\
\hline \multicolumn{5}{|l|}{$\begin{array}{c}\text { Yearly } \\
\text { (from 1744) }\end{array}$} \\
\hline $1744-45$ & $19.5 \%$ & $0.3 \%$ & $27.9 \%$ & $6.9 \%$ \\
\hline $1745-46$ & 24.6 & 16.3 & 24.0 & 16.7 \\
\hline $1746-47$ & 33.5 & -7.1 & 32.1 & -7.4 \\
\hline $1747-48$ & 65.9 & - & 24.8 & - \\
\hline $1748-49$ & 2.4 & - & -22.2 & - \\
\hline
\end{tabular}

Table 2 Price Levels in Massachusetts: 1720-49 (wholesale price per bushel or gallon)

\begin{tabular}{|c|c|c|c|c|}
\hline \multirow[b]{2}{*}{$\begin{array}{c}\text { Every } 5 \text { th } \\
\text { Year' }\end{array}$} & \multicolumn{2}{|c|}{ Wheat } & \multicolumn{2}{|c|}{ Molasses } \\
\hline & $\begin{array}{l}\text { Mass. } \\
\text { Shillings }\end{array}$ & $\begin{array}{l}\text { Silver- } \\
\text { Equivalence } \\
\text { Units*. }\end{array}$ & $\begin{array}{l}\text { Mass. } \\
\text { Shillings }\end{array}$ & $\begin{array}{l}\text { Silver- } \\
\text { Equivalence } \\
\text { Units* }\end{array}$ \\
\hline 1720 & 7.00 & 3.98 & 2.00 & 1.14 \\
\hline 1725 & 8.73 & 3.93 & 2.00 & .90 \\
\hline 1730 & 10.75 & 3.76 & 3.00 & 1.05 \\
\hline 1735 & 13.25 & 3.38 & 4.73 & 1.21 \\
\hline 1740 & 13.00 & - & 8.00 & - \\
\hline 1745 & 17.92 & 3.49 & 9.54 & 1.86 \\
\hline 1749 & 50.25 & 5.85 & 15.17 & 1.77 \\
\hline
\end{tabular}

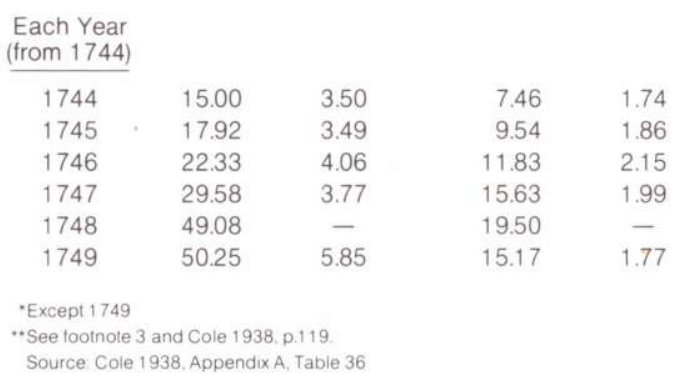

Inflation and the Money Supply

Over a period of sufficient length, most economists would conjecture that large-scale inflation and currency depreciation must be due to sustained growth in the money supply relative to growth in production. However, this is far from being the case over most of the period between 1720 and 1749. As indicated in Table 4, from 1720 to 1740 Massachusetts' per capita note issue first rose and then fell fairly rapidly for 15 years. ${ }^{4}$ From 1725 to 1730 the per capita level of notes in circulation declined 7 percent; at the same time, the price of wheat rose 33 percent and the price of molasses rose 50 percent. From 1730 to 1735 the per capita level of notes in circulation declined 13 percent, yet the price of wheat rose 23 percent and the price of molasses rose 58 percent. From 1735 to 1740 , per capita note issue declined 16 percent; this was accompanied by a 2 percent decline in wheat prices and a 69 percent rise in the price of molasses. The net picture over the period $1725-40$ is that Massachusetts' per capita note circulation in 1740 was only 68 percent of its 1725 level, while wheat was 1.5 times as expensive and molasses was 4 times as expensive in 1740 as in 1725 .

After 1740 a large increase in Massachusetts' per capita note issue is apparent. Between 1740 and 1750 the per capita level of notes issued increased 5.6 times; at the same time, wheat prices rose 287 percent, the price of molasses rose 90 percent, and Massachusetts notes depreciated 97 percent. Thus, over the last ten years of the

\footnotetext{
${ }^{4}$ The per capita level of note issue is used as a proxy for the level of currency issue relative to the size of the economy; that is, population proxies for gross national product. Since the Industrial Revolution was not yet under way, it is not unreasonable to roughly equate population growth with economic growth.
} 
Table 3

\section{The value of Massachusetts currency depreciated substantially between 1720 and 1749.}

Table 3 Massachusetts Exchange Rates and Rates of Depreciation: 1720-49

\begin{tabular}{lrcc} 
Year & & $\begin{array}{c}\text { Mass.£per£100 } \\
\text { British Sterling }\end{array}$ & \%Depreciation \\
\cline { 3 - 4 } 1720 & & £219.43 & - \\
1725 & & 289.11 & $31.8 \%$ \\
1730 & & 337.71 & 16.8 \\
1735 & 360.00 & 6.6 \\
1740 & 525.00 & 45.8 \\
1744 & 588.61 & 12.1 \\
1745 & 644.79 & 9.5 \\
1746 & 642.50 & -0.4 \\
1747 & 925.00 & 44.0 \\
1748 & 912.50 & -1.4 \\
1749 & $1,033.33$ & 13.2
\end{tabular}

Source of basic data: McCusker 1978, pp. 140-41 period, inflation and currency depreciation are associated with large increases in the quantity of notes in circulation relative to growth in the size of the economy.

In general, then, while there were periods when high rates of money growth were accompanied by high inflation, there was a 15-year period of declining note circulation in which inflation and currency depreciation continued unabated. Thus, the quantity of money issued by Massachusetts itself (or its money growth rate) appears not to explain a great deal of the inflationary experience of the colony from 1720 to 1749 .

However, it is also the case that prior to 1750 all New England currencies exchanged at par and that the notes of New Hampshire, Connecticut, and Rhode Island circulated in Massachusetts. Therefore, it might be argued that (up until 1750) it is not adequate to consider Massachusetts' money supply in isolation; instead, price and exchange rate movements should be compared to the per capita stock of all New England notes in circulation.

When this approach is followed, the quantity theory fares much better. For instance, as can be seen in Table 5, from 1720 to 1740 the per capita money supply of New England rose by a factor of 1.85 . So did Massachusetts' wheat prices. Similarly, after 1740 New England as a

Tables 4 and 5

\begin{abstract}
Although there was a slight decrease in Massachusetts' money supply between 1725 and 1740, the overall money supply of New England increased steadily.
\end{abstract}

Table 4 Nominal Per Capita Note Issue in Massachusetts: 1720-50

Mass. $£$

\begin{tabular}{|c|c|c|}
\hline Year & per 1,000 people & $\%$ Chan \\
\hline 1720 & $£ 2,087$ & - \\
\hline 1725 & 3,171 & $52 \%$ \\
\hline 1730 & 2,938 & -7 \\
\hline 1735 & 2,556 & -13 \\
\hline 1740 & 2,159 & -16 \\
\hline 1745 & 4,824 & 123 \\
\hline 1750 & 12,257 & 154 \\
\hline
\end{tabular}

Table 5 Nominal Per Capita Note Issue in New England: 1720-50

\begin{tabular}{|c|c|c|}
\hline Year & $\begin{array}{c}\text { Colonial } £ \\
\text { per } 1,000 \text { people }\end{array}$ & $\%$ Change \\
\hline 1720 & $£ 1,620$ & - \\
\hline 1725 & 2,300 & $42 \%$ \\
\hline 1730 & 2,277 & -1 \\
\hline 1735 & 2,770 & 22 \\
\hline 1740 & 3,038 & 10 \\
\hline 1745 & 6,259 & 106 \\
\hline 1750 & 10,869 & 74 \\
\hline
\end{tabular}

Sources of basic data: Brock 1975, pp. 591-93; U.S. Bureau of the Census 1975, Series Z1-19, p. 1168; my interpolations of some population figures 
whole experienced the same rapid monetary growth already noted for Massachusetts, and again New England monetary increases match up fairly well with Massachusetts' price level movements. In short, when the paper currency supply of New England as a whole is considered, the quantity theory seems to account fairly well for the inflationary experiences of the region before 1750 .

\section{Inflation and the Backing of Notes}

Although the quantity theory accounts for much of Massachusetts' inflationary experience between 1720 and 1749 , the Sargent-Wallace view (that the nature of backing for currency determines its value) is also consistent with the events of this period. ${ }^{5}$ This view suggests that the value of colonial notes, which were backed by the future receipts of the loan office and by future tax receipts of the colony, should have declined largely as a result of speculation regarding these receipts. If this view is correct, the severe inflation and currency depreciation documented above should be attributable to inadequate backing of notes.

In fact, according to Brock (1975, Table IIA), by 1740 , 64 percent of the paper currency stock of Massachusetts consisted of notes which were overdue for retirement. Thus it is clearly the case that the colony was doing a relatively poor job of honoring its commitments to back notes with future income streams. Some reasons for this poor showing will be elaborated here to indicate the extent to which many of the note issues of Massachusetts were inadequately backed, and hence to document that the Sargent-Wallace view is consistent with the inflationary experiences of Massachusetts prior to 1750 .

It will be recalled that a substantial component of the money supply of Massachusetts consisted of notes issued through the colonial loan office. It will also be recalled that these notes were supposed to be backed, first by the repayment of principal on loans and second (in the event of default) by the receipts obtained from auctioning mortgaged property. A poor record for the loan office of receiving repayment of principal or receipts from auctioned property would help to account, then, for the declining value of Massachusetts currency.

In fact, it is easy to document that the backing for land-bank notes was inadequate to maintain their value. The backing was inadequate, if for no other reason than that provisions of the laws regulating land bank operations were poorly administered. As stated by Thayer (1953, p. 157),
Many of the early land-bank laws, especially in New England, did not make provision for yearly payments on the principal. As a result, when the loans came due the borrow-ers, more often than not, were unable to pay off their debt. Instead of foreclosing on the mortgages as required by the provisions of the law, the legislatures usually extended time to the delinquents. When the first issue became due in Massachusetts in 1719 less than one half of the principal had been paid. Ten years later most of the loans had been repaid, but it was another decade before all of the accounts were settled. The same story holds for the other loan issues in Massachusetts, notwithstanding the fact that the laws after about 1720 required both interest and principal to be paid on a yearly basis.

Thus, the first form of backing for these notes-repayment of principal-was often delinquent or not forthcoming at all.

Moreover, when principal was not repaid or foreclosure took place due to delinquency, the government was supposed to retire notes obtained by auctioning the property securing the loan. Since land banks were not supposed to lend more than half the value of mortgaged property, it would seem that this recourse in the event of loan default should have provided adequate backing for notes. However, Thayer (1953, p. 153) suspects that "in New England ... the evaluators [of loans] paid slight regard to this requirement, permitting loans to be made with very inadequate security." It would seem, then, that provisions meant to provide adequate backing for landbank note issues were not respected in practice. In consequence, these note issues were inadequately backed; therefore it may be concluded that the history of currency values in Massachusetts before 1750 is consistent with the Sargent-Wallace view. Moreover, it will now be seen that this view is also consistent both with the way in which inflation was halted and with post-1750 experience, whereas the quantity theory is not.

\section{The Currency Reform of $\mathbf{1 7 5 0}$}

In light of the continually diminishing value of its currency, it is not surprising that by 1740 reform of the monetary system of Massachusetts had become the colony's most important and divisive political issue. In 1748 a proposal for currency reform was placed before the colonial legislature, and reform legislation was passed in

${ }^{5}$ This is not surprising, of course, in light of the fact that when money is poorly backed or unbacked, the quantity theory becomes a special case of the Sargent-Wallace view. 
1749. Its basic substance was as follows. A transfer of specie was due from London as compensation for expenses incurred in King George's War. This specie was to be exchanged for the colony's outstanding notes at specified rates until all existing currency had been returned or until March 31, 1750, at which date the old currency was to become valueless. If there was insufficient specie to retire all notes, the shortfall was to be made up by tax receipts.

In addition, the government of Massachusetts attempted to convince New Hampshire, Rhode Island, and Connecticut to undertake a similar reform. When these colonies refused, Massachusetts enacted a penalty for passing their notes within its borders. Thus, in 1750 paper currency was to have been completely eliminated in Massachusetts.

However, it will be recalled that one of the reasons for establishing land banks had been to alleviate a shortage of specie, particularly in smaller denominations. The specie received from England apparently did not solve this problem. As paper currency was retired this led to riots, and in light of the shortage of specie, taxpayers petitioned the legislature to provide some kind of new paper money. In particular, these petitioners complained that they were unable to obtain money of any kind to pay their taxes and, as a result, their property was being seized and auctioned at a fraction of its true value.

In response to this need for a new kind of paper medium, the colony decided to issue treasury notes, which were paper liabilities representing money borrowed by Massachusetts. Treasury notes replaced earlier bills of credit in the colony and are what historians mean when they refer to paper money in Massachusetts after 1750 . The treasury notes differed from bills of credit in several ways. Although they were negotiable bearer notes, treasury notes could not be used as legal tender to repay debts, as could bills of credit; however, this difference was not important enough to limit their circulation. More significant was the fact that treasury notes were interest-bearing, whereas earlier bills were not. And most important, treasury notes were convertible on demand into specie. Thus, Massachusetts converted its monetary system from one with a weakly backed paper currency to one where the government stood committed to increase its assets in conjunction with any further note issues.

\section{The Effects of the Reform: 1750-54}

Already in 1749, as reform legislation was passed, inflation in Massachusetts declined considerably. That year the price of wheat rose only about 2 percent and the price of molasses fell 22 percent. Table 6 provides price levels and inflation rates for these commodities for the interval 1750-54. During those five years, inflation rates ranged between -10.9 percent and 5.1 percent. This contrasts considerably with the interval 1744-48, when annual inflation of commodity prices was never less than 19.5 percent. The cumulative price change for 1750-54 was 4.8 percent for wheat and -10.3 percent for molasses. Thus, over the first five years after the currency reform, the price of wheat rose, on average, less than 1 percent per year and the price of molasses fell about 2 percent per year. Over the previous five years, inflation had averaged over 29 percent per year for wheat prices and over 17 percent per year for molasses prices. Thus, the problem of inflation in colonial Massachusetts was solved through the 1750 currency reform.

Data for exchange rates are presented in Table 7 , which shows monthly (as available) values for the exchange rate between Massachusetts currency and British pounds sterling. As is readily apparent, the value of the exchange rate fluctuated dramatically before the currency reform. Also, it has been seen that the value of Massachusetts currency depreciated substantially before 1750 . After 1750 this picture is reversed. Over the period of January 1750-December 1757, 32 monthly observations on the exchange rate are available. In only 6 months of this period does the exchange rate deviate from 133.33. Clearly, then, currency depreciation was immediately arrested by the reform. In fact, from January 1750 to December 1757 there was a 12.5 percent appreciation in the value of Massachusetts notes in terms of British sterling.

In addition, the violent month-to-month fluctuations in the exchange rate were halted by the currency reform. As noted, in only 6 of 32 months of available observations did the exchange rate deviate from 133.33. Five of these months were the first 5 observations available immediately following the reform. By November 1750 the exchange rate had reached 133.33, and after that only once in 26 months of observations did the exchange rate vary at all.

This stability in post-reform exchange rates is remarkably at variance with pre-1750 experience. In 1745 the December exchange rate was only 3 percent higher than the January value. But in the interim, the April value had been 27 percent higher than the March value. In 1749 the December value was 15 percent higher than the April value. Thus, the reform ended not only the long-standing 
Tables 6 and 7

\section{Massachusetts' currency reform stabilized prices and exchange rates.}

\section{Table 6 Price Levels and Inflation Rates in Massachusetts: 1750-54 \\ (wholesale prices in Mass. shillings per bushel or gallon)

\begin{tabular}{|c|c|c|c|c|}
\hline \multirow[b]{2}{*}{ Year } & \multicolumn{2}{|c|}{ Wheat } & \multicolumn{2}{|c|}{ Molasses } \\
\hline & Price & $\%$ Inflation & Price & $\%$ Inflation \\
\hline 1750 & 4.79 & - & 1.84 & - \\
\hline 1751 & 4.55 & $-5.0 \%$ & 1.64 & $-10.9 \%$ \\
\hline 1752 & 4.78 & 5.1 & 1.70 & 3.7 \\
\hline 1753 & 4.74 & -0.8 & 1.77 & 4.1 \\
\hline 1754 & 5.02 & 5.9 & 1.65 & -6.8 \\
\hline
\end{tabular}

Table 7 Massachusetts Exchange Rates Before and After the Currency Reform of 1750 (Mass. £ per £100 British sterling)

\begin{tabular}{|c|c|c|c|}
\hline \multicolumn{2}{|c|}{ Before Reform } & \multicolumn{2}{|c|}{ After Reform } \\
\hline Date* & Rate & Date* & Rate \\
\hline \multirow{13}{*}{$\begin{array}{l}1745: \\
\text { January } \\
\text { February } \\
\text { March } \\
\text { April } \\
\text { May } \\
\text { June } \\
\text { July } \\
\text { August } \\
\text { September } \\
\text { October } \\
\text { November } \\
\text { December } \\
\text { Average }\end{array}$} & \multirow{13}{*}{$\begin{array}{r}£ 600.00 \\
550.00 \\
550.00 \\
700.00 \\
700.00 \\
570.00 \\
700.00 \\
700.00 \\
700.00 \\
700.00 \\
650.00 \\
617.50 \\
644.79\end{array}$} & \multirow{8}{*}{$\begin{array}{l}\text { 1750: } \\
\text { January } \\
\text { April } \\
\text { June } \\
\text { September } \\
\text { October } \\
\text { November } \\
\quad \text { Average }\end{array}$} & \\
\hline & & & $£ 150.00$ \\
\hline & & & 150.00 \\
\hline & & & 135.33 \\
\hline & & & 126.67 \\
\hline & & & 126.67 \\
\hline & & & 133.33 \\
\hline & & & 137.33 \\
\hline & & \multirow{3}{*}{$\begin{array}{l}\text { 1751: } \\
\text { May } \\
\text { Average }\end{array}$} & \\
\hline & & & 133.33 \\
\hline & & & 133.33 \\
\hline & & \multirow{4}{*}{$\begin{array}{l}\text { 1753: } \\
\text { March } \\
\text { May } \\
\text { Average }\end{array}$} & \\
\hline & & & 126.67 \\
\hline 1746: & \multirow{5}{*}{$\begin{array}{l}585.00 \\
700.00 \\
642.50\end{array}$} & & $\begin{array}{l}133.33 \\
13000\end{array}$ \\
\hline $\begin{array}{l}\text { January } \\
\text { September }\end{array}$ & & & 130.00 \\
\hline $\begin{array}{l}\text { September } \\
\text { Average }\end{array}$ & & \multirow{3}{*}{$\begin{array}{l}\text { 1754: } \\
\text { February } \\
\text { Average }\end{array}$} & \\
\hline $\begin{array}{l}\text { Average } \\
1747:\end{array}$ & & & 133.33 \\
\hline $\begin{array}{l}\text { 1747: } \\
\text { June }\end{array}$ & & & 133.33 \\
\hline $\begin{array}{l}\text { June } \\
\text { September }\end{array}$ & 950.00 & \multirow{3}{*}{$\begin{array}{l}1755-57 \\
\text { Each month, } \\
22 \text { observations }\end{array}$} & \\
\hline December & 950.00 & & 133.33 \\
\hline Average & 925.00 & & \\
\hline \multirow{3}{*}{$\begin{array}{l}\text { 1748: } \\
\text { March } \\
\text { July } \\
\text { Average }\end{array}$} & & & \\
\hline & 950.00 & & \\
\hline & $\begin{array}{l}875.00 \\
912.50\end{array}$ & & \\
\hline \multicolumn{2}{|l|}{$1749:$} & & \\
\hline January & $1,000.00$ & & \\
\hline April & 975.00 & & \\
\hline $\begin{array}{l}\text { December } \\
\text { Average }\end{array}$ & $1,125.00$ & & \\
\hline Average & $1,033.33$ & & \\
\hline
\end{tabular}

Table 8

\section{Other New England currencies depreciated against the British pound around the time of Massachusetts' currency reform.}

\author{
Table 8 Exchange Rates for Other \\ New England Currencies: 1749-56* \\ (colonial £ per £100 British sterling)
}

\begin{tabular}{ccccc} 
Year & & New Hampshire & Rhodelsland & Connecticut \\
\cline { 5 - 6 } 1749 & & $£ 1,122.58$ & $£ 1,161.29$ & $£ 1,103.23$ \\
1750 & $1,003.16$ & $1,224.52$ & $1,025.81$ \\
1751 & & $1,133.42$ & $1,244.52$ & - \\
1752 & $1,222.26$ & $1,333.36$ & $1,248.39$ \\
1753 & $1,266.77$ & $1,555.55$ & $1,258.06$ \\
1754 & $1,333.36$ & $1,666.84$ & $1,335.48$ \\
1755 & $1,555.55$ & $1,889.03$ & $1,432.26$ \\
1756 & $2,000.13$ & $2,333.42$ & $133.33^{* *}$
\end{tabular}

*Exchange rates computed at the standard market price of silver in London * Change of units caused by Connecticut's currency reform

Source: McCusker 1978, p. 153

currency depreciation, but short-term fluctuations in the exchange rate as well.

One might question, of course, whether the stability of currency values after 1750 was due solely to the currency reform or whether other factors might have been largely responsible. This question can be answered by considering the contemporaneous experiences of Massachusetts' neighboring colonies. To this end, Table 8 presents annual exchange rates for the currencies of New Hampshire, Rhode Island, and Connecticut. From 1750 until 1756, New Hampshire's currency depreciated 99 percent and Rhode Island's depreciated 88 percent. From 1750 until 1755, Connecticut's currency depreciated 40 percent (a currency reform occurred there in 1756). Thus, despite the continuing extreme depreciation of neighboring currencies, Massachusetts was able to prevent depreciation via its currency reform.

\section{The Post-Reform Years: 1755-70}

It remains to consider why the 1750 currency reform succeeded in so rapidly ending Massachusetts' inflation and currency depreciation. According to the view that, at least over longer periods, money growth is responsible for inflation, this achievement must have been accomplished 
via a reduction in the growth rate of the money supply. In fact, over the period $1750-55$ such a reduction appears to have occurred. ${ }^{6}$ This might seem to suggest that a quantity theoretic interpretation of this period is valid. However, after 1755, note issue in Massachusetts increased tremendously. Despite this massive growth in the money supply, inflation was not rekindled.

Table 9 presents data on per capita note circulation in Massachusetts from 1755 onward. Note that growth in the per capita money supply was extremely high. From 1755 to 1760 , per capita note issue rose 792 percent. From 1760 to 1765 , it declined substantially, but there were still six times as many notes per capita circulating as in 1755 . From 1765 to 1770 , per capita note issue declined 72 percent, but the per capita money supply was still 1.7 times as large as in 1755 . Thus, the years from 1755 to 1770 witnessed a large increase in the note circulation of Massachusetts. ${ }^{7}$

The reason for the large increase in notes was that this growth financed the government deficits created by expenditures for the French and Indian War (1756-63). The wartime period was one of large government deficits and high rates of money growth. The inflationary experience of this period does not reflect either factor, however. Table 10 presents price level data for Massachusetts during $1755-70$. From 1755 to 1760 , the price of wheat rose 12 percent and the price of molasses rose 42 percent. The annual average increases over this five-year interval were around 2 percent for wheat prices and around 8 percent for molasses prices. These annual average increases are much lower than the annual rates of inflation that were typical of 1744-48. In fact, this is an extremely mild wartime inflation, particularly in light of the magnitude of money growth over the period. ${ }^{8}$

After 1760 there was a large reduction (31 percent) in the supply of notes per capita as the population grew and as notes were, on average, retired from circulation. This reduction was accompanied by declining prices of both commodities. Despite this rapid retirement of notes, however, the per capita level of note issue was still six times larger in 1765 than in 1755 . Even so, the price of wheat was 5 percent lower and the price of molasses was 22 percent lower than in 1755 . In the face of a sixfold increase in the quantity of notes in circulation, these declining commodity prices are difficult to reconcile with any version of the quantity theory. Or, to put the same point differently, it is clear from this episode that it is not always necessary to tightly control money growth in or- der to control inflation.

Again, from 1765 to 1770 , there was a decline in note issue per capita in Massachusetts of 72 percent. It is an interesting contrast to note that, during this interval where the per capita money supply fell, prices of commodities rose. Over this five-year period, the prices of wheat and molasses both rose 10 percent. Also, it will be noted that in spite of the decline in note circulation after 1760 , in 1770 the per capita level of note circulation was still substantially higher than in 1755 . Nevertheless, the price of wheat was only 5 percent higher and the price of molasses was 14 percent lower in 1770 than in 1755 .

Two general points are worthy of note. First, money growth rates and inflation rates do not match up in any way. Second, the inflationary experiences of post-reform Massachusetts are particularly mild, despite extremely rapid rates of note issue by the colonial government.

The picture with regard to exchange rates is perhaps even more striking. Table 11 presents data on the exchange rate between Massachusetts notes and British pounds sterling for 1755-70. As can be seen, from 1755 to 1760 Massachusetts notes appreciated in spite of the large amount issued. From 1760 to 1765 the colony's notes depreciated 3 percent in the face of the 31 percent reduction in per capita notes outstanding. Over the decade $1755-65$, the notes depreciated 0.2 percent despite the 6-fold increase in circulating notes.

In summary, all of the intervals 1755-60, 1755-65, and 1755-70 display high rates of growth in the money supply of Massachusetts. From 1755 until 1770, per capita note issue in Massachusetts rose 70 percent. Despite this increase in the money supply, the price of wheat was only 5 percent higher (an average growth of about 0.3 percent per year) and the price of molasses was 14 percent lower in 1770 than in 1755 . Over the same period, the

\footnotetext{
${ }^{6} \mathrm{Money}$ supply figures for $1750-54$ are not presented because new treasury notes and earlier bills of credit coexisted for a brief period after the reform. Since these bills were differently denominated, no summary measure does justice to total note circulation.

${ }^{7}$ By 1774 , per capita note issue in Massachusetts had dropped to $£ 226$ (Massachusetts currency).

${ }^{8}$ As a standard for comparison, during World War II (1940-45) base money per capita in the United States rose 101 percent, M2 per capita rose 127 percent, the consumer price index rose 28 percent, and the wholesale price index rose 35 percent. In contrast, from 1755 to 1760 base money issued by the government of Massachusetts grew more than five times as fast as did base money issued by the United States in World War II. Nevertheless, the inflationary experiences are comparable; moreover, during World War II, price controls were required to suppress inflation.
} 
Tables 9, 10, and 11

\section{Despite large increases in the colony's money supply, Massachusetts' prices and exchange rates were stable between 1755 and 1770 .}

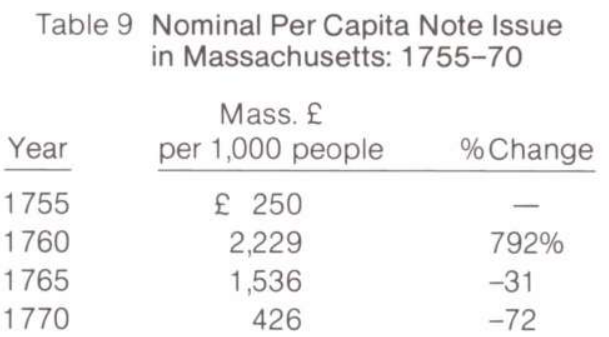

Sources of basic data: Brock 1975, p. 596; U.S. Bureau of the Census 1975. Series Z1-19, p. 1168 my interpolations of some population figures

Table 10 Price Levels and Inflation Rates in Massachusetts: $1755-70$ (wholesale prices in Mass. shillings per bushel or gallon)

\begin{tabular}{|c|c|c|c|c|}
\hline \multirow[b]{2}{*}{ Year } & \multicolumn{2}{|c|}{ Wheat } & \multicolumn{2}{|c|}{ Molasses } \\
\hline & Price & $\%$ Inflation & Price & $\%$ Inflation \\
\hline 1755 & 5.14 & $2.4 \%$ & 1.59 & $-3.6 \%$ \\
\hline 1756 & 4.95 & -3.7 & 1.62 & 1.9 \\
\hline 1757 & 4.48 & -9.5 & 2.05 & 26.5 \\
\hline 1758 & 4.56 & 1.8 & 2.02 & -1.5 \\
\hline 1759 & 5.56 & 21.9 & 2.48 & 22.8 \\
\hline 1760 & 5.76 & 3.6 & 2.26 & -8.9 \\
\hline 1761 & 5.53 & -4.0 & 2.02 & -10.6 \\
\hline 1762 & 6.10 & 10.3 & 1.71 & -15.3 \\
\hline 1763 & 6.33 & 3.8 & 1.52 & -11.1 \\
\hline 1764 & 5.04 & -20.4 & 1.34 & -11.8 \\
\hline 1765 & 4.90 & -2.8 & 1.24 & -7.5 \\
\hline 1766 & 5.34 & 9.0 & 1.32 & 6.5 \\
\hline 1767 & 5.90 & 10.5 & 1.29 & -2.3 \\
\hline 1768 & 6.00 & 1.7 & 1.30 & 0.8 \\
\hline 1769 & 5.23 & -12.8 & 1.38 & 6.2 \\
\hline 1770 & 5.39 & 3.1 & 1.37 & -0.7 \\
\hline
\end{tabular}

Source of basic data: Cole 1938, Appendix A, Table 36
Table 11 Massachusetts Exchange Rates and Rates of Depreciation: 1755-70

\begin{tabular}{|c|c|c|}
\hline Year & $\begin{array}{c}\text { Mass. } £ \text { per } £ 100 \\
\text { British Sterling }\end{array}$ & \% Depreciation \\
\hline 1755 & $£ 133.33$ & - \\
\hline 1756 & 133.33 & $0.0 \%$ \\
\hline 1757 & 133.33 & 0.0 \\
\hline 1758 & 128.34 & -3.7 \\
\hline 1759 & - & - \\
\hline 1760 & 129.54 & - \\
\hline 1761 & 140.10 & 8.2 \\
\hline 1762 & 142.33 & 1.6 \\
\hline 1763 & 136.00 & -4.4 \\
\hline 1764 & 133.75 & -1.7 \\
\hline 1765 & 133.54 & -0.2 \\
\hline 1766 & 133.03 & -0.4 \\
\hline 1767 & 133.33 & 0.2 \\
\hline 1768 & 133.33 & 0.0 \\
\hline 1769 & 129.86 & -2.6 \\
\hline 1770 & 126.31 & -2.7 \\
\hline
\end{tabular}


value of Massachusetts currency in terms of pounds sterling appreciated 5 percent. Thus, extremely large money growth rates led neither to inflation nor to currency depreciation in the post-reform period.

\section{An Explanation: The Role of Fiscal Policy}

Obviously, the history of Massachusetts after 1755 is completely inconsistent with the view that, over a sufficiently long period, money growth rates determine the rate of inflation. Post-reform history is, however, quite consistent with the Sargent-Wallace view that money is valued according to how it is backed. After 1755 the government of Massachusetts ran large deficits, which for all practical purposes may be viewed as being completely monetized. Prevailing theories of money and the inflationary process suggest that, in light of the large growth rates in the money supply, severe inflation should have resumed. This is even more the case in the presence of the sustained government deficits that existed. Nevertheless, from 1755 to 1765 , while the per capita money supply increased by a factor of more than 6 , prices fell.

This apparently strange phenomenon is easily explained by considering the nature of backing for notes. In particular, government deficits were financed by printing notes to cover temporary shortfalls of income relative to expenditures and, at the same time, levying taxes due at a specified future date for retiring the notes so issued. The mechanism by which this was done was as follows. Given that a current deficit was to be financed by issuing notes, a tax would be levied at some future date or dates. This tax could be paid using notes, which would then not be recirculated, or it could be paid using specie, which would then be used to purchase notes and retire them from circulation. Thus all notes were, in effect, claims to future tax receipts so that they were backed in an obvious way. All evidence indicates that they were also backed carefully; that is, future taxes for retiring notes appear to have been amply provided. Such backing of notes appears to have been sufficient to prevent inflation even in the face of rapid money growth.

Notice, then, that fiscal rather than monetary policy was responsible for maintaining stable prices and exchange rates. However, it was clearly not the case that price stability was achieved by balancing the colonial budget, at least in any yearly sense. Rather, the method of backing notes precluded the running of continual deficits, while accommodating needs for even substantial short-term deficit financing. Thus, the fiscal policy which contributed to price stability was not short-run, but rather, in some sense, long-run average balancing of the budget.

\section{Other Experiences Beyond Massachusetts}

It has been seen that after the currency reform of 1750 , price level and exchange rate movements were not easily accounted for by the monetary policy of the colony of Massachusetts. Smith $(1983 a, b)$ provides similar evidence for other American colonies and also provides evidence that, throughout the colonies, the nature of backing for money accounted for how successfully or unsuccessfully stable prices and currency values were maintained. Thus, the Massachusetts incidents discussed are not isolated, but rather they indicate the general tenor of colonial monetary experience. In addition, Sargent (1981) presents evidence on currency reforms which ended hyperinflations in four twentieth-century European economies. In general, the nature of these reforms is similar to Massachusetts' in the eighteenth century. Thus, significant historical evidence suggests that appropriate fiscal policy is crucial in controlling an economy's inflation rate.

A natural final question is whether there are important differences between modern economies and the ones mentioned above that would prevent the same kinds of policies from being used to control inflation. One difference that might concern many economists is the nature of contracting arrangements. In particular, some economists have argued that the presence of overlapping wage contracts severely restricts the set of government policies which can be used to control inflation. (See, for example, Taylor 1982 or Thurow 1982.) Economists who adopt such a view argue that the currency reforms discussed by Sargent (1981) could work only because inflation was so severe that nominal contracting arrangements broke down completely, thereby removing an important impediment to policy.

This argument, however, does not pertain to contracting arrangements in colonial Massachusetts. In fact, it is easy to document that nominal contracting arrangements were widespread in the colony and did not break down as a result of inflation (Smith 1983a). Thus, the reform of 1750 and subsequent careful backing of note issues halted a severe inflation of long duration and prevented it from arising again despite massive note issues and the prevalence of nominal contracting arrangements. 


\section{Conclusion}

The general tenor of colonial monetary experience suggests that the manner in which money is backed (or whether it is backed at all) is perhaps the most important determinant of its value. This point has been made here by looking in detail at the history of colonial Massachusetts. However, as Sargent (1981) and Smith (1983a,b) have demonstrated, it is a point which applies quite generally in monetary history. Moreover, it is a point which contains many lessons for modern monetary policy. One lesson in particular is that the time path of government deficits and surpluses is integrally related to the inflationary impact of changes in the money supply. Hence, fiscal policy plays a crucial role in determining the level of inflation that an economy experiences.

This point raises an important question, however: Does the provision of backing for notes (that is, a commitment to run an appropriate fiscal policy) impose some severe social costs that would outweigh the benefits associated with enhanced price level stability? Again, there is a lesson provided by the Massachusetts experience. In the colonial period, recessions were associated with contractions in the volume of imports and exports. While only trade volumes with England and Scotland are available, these indicate that the currency reform period was one of enhanced (rather than reduced) international trade (U.S. Bureau of the Census, pp. 1176-78). Hence, to all appearances, Massachusetts accomplished its monetary reform with a minimum of economic disruption. A similar conclusion about the currency reforms that ended four European hyperinflations emerges from the evidence provided by Sargent (1981). In short, it appears that a commitment on the part of a government to back new issues of liabilities with future surpluses is sufficient to control inflation, and moreover, to do so with a minimum of economic disruption.

\section{References}

Brock, Leslie V. 1975. The currency of the American colonies, 1700-1764: A study in colonial finance and imperial relations. New York: Arno Press.

Cole, Arthur H. 1938. Wholesale commodity prices in the United States, 1700-1861. Cambridge: Harvard University Press.

Hanson, John R., II. 1979. Money in the colonial American economy: An extension. Economic Inquiry 17 (April): 281-86. 1980. Small notes in the American colonies. Explorations in Economic History 17: 411-20.

Lester, Richard A. 1938. Currency issues to overcome depressions in Pennsylvania, 1723 and 1729. Journal of Political Economy 46 (June): 324-75.

1939. Currency issues to overcome depressions in Delaware, New Jersey, New York and Maryland, 1715-37. Journal of Political Economy 47 (April): 182-217.

McCusker, John J. 1978. Money and exchange in Europe and America, 1600-1775: A handbook. Chapel Hill: University of North Carolina Press.

Sargent, Thomas J. 1981. The ends of four big inflations. Research Department Working Paper 158. Federal Reserve Bank of Minneapolis. Also 1982, in Inflation: Causes and effects, ed. Robert E. Hall, pp. 41-97. National Bureau of Economic Research Project Report. Chicago: University of Chicago Press.

Smith, Bruce D. 1983a. American colonial monetary regimes: The failure of the quantity theory and some evidence in favor of an alternate view. Research Department Working Paper 234. Federal Reserve Bank of Minneapolis.

. 1983b. Some colonial evidence on two theories of money: Maryland and the Carolinas. Research Department Working Paper 245. Federal Reserve Bank of Minneapolis.

Taylor, John. 1982. Union wage settlements during a disinflation. American Economic Review 73 (December): 981-93.

Thayer, Theodore. 1953. The land-bank system in the American colonies. Journal of Economic History 13 (Spring): 145-59.

Thurow, Lester C. 1982. Is inflation really cured? Newsweek (November 22): 104.

U.S. Bureau of the Census. 1975. Historical statistics of the United States, colonial times to 1970. Bicentennial edition, Part 2. Washington, D.C.: U.S. Government Printing Office.

Vogel, Robert C. 1974. The dynamics of inflation in Latin America, 1950-1969. American Economic Review 64 (March): 102-14.

Wallace, Neil. 1981. A Modigliani-Miller theorem for open market operations. American Economic Review 71 (June): 267-74. 